\title{
SUCCESSFUL ADAPTATION OF THE ADOPTED CHILD AS A FACTOR OF SOCIALIZATION
}

Удк: $159.9-058.862: 316.35 .023 .4$

\section{Melnychuk T.}

Ph.D., senior scientist, Laboratory of the Organizational and Social Psychology, G.S. Kostiuk Institute of Psychology at the National Academy of Educational Sciences of Ukraine, Kyiv (Ukraine)

Annotation. Considered the importance of information disclosure to the child about the fact of adoption and her life story with the disclosure of blood genetic origin. Revealed that the secret of adoption was the public domain, which is included in individual family life according to the levels and depths access of its members to information on adoption. The awareness and knowledge of the child information about their genetic origins serve as an important mechanism for identifying which from early childhood performs functions development her identity and socialization.

Keywords: adoption, socialization, identification of the child and selfdetermination.

The relevance of study of the social and psychological factors of children's adoption efficiency in the Ukraine and abroad motivated by the increasing number of failed adoptions cases, which lead to psycho trauma of adults and children, and sometimes has tragic consequences. The necessity to research the problems is also caused by the fact that in Ukraine, as well as around the world, every year the number of families who cannot have children is increasing, as well as the number of children, who because of certain circumstances stay without a family. The analysis of psychological, medical and sociological studies revealed that childlessness often leads to conflict between a couple and the subsequent break of family relations. [1, 2, 3, 4] However, for any society or state is important not only to ensure the stability of the family and abandonment of poverty, but creating such environment where a child would live and grow up with loving parents who primarily operate in the best interests of the child, maintain stable and favorable condi- 
tions of life and mental development. So a family, that adopts a child, felt that their family is having a baby through their hearts and they certainly took it as their biological.

Exploring social and psychological factors of children's adoption effectiveness in Ukraine, we have found that exactly the sociopsychological readiness of a family for the parenthood and its psychological maturity will provide positive result in the adoption process and further successful adaptation of children in a new family that will reduce the number of reorphaning of children.

The purpose of the article is to isolate and systematically describe the factors that lead to the decision to adopt a child and have a positive impact on the occurrence of the family motif for adoption, which in the future will ensure the effectiveness of children adoption, successful adaptation to a new family and their socialization in the society.

\section{Theoretical basis of the research.}

Today in the Ukraine the institution of adoption, as a socio-psychological phenomenon is unexplored, it is primarily due to the complexity and closeness of the adoption process, lack of psychological preparedness of the researched problem as scientific. In the study of psychological readiness of parents to adoption is important not only parents age, their housing and living conditions, financial situation, but more their social maturity, awareness, acceptance of nonnative children. It should be emphasized that in the conclusion provision of the Ukrainian citizens «On their possibility to be adoptive parents» exactly the psychological maturity of a couple barely studied, the survey is done without considering the social and psychological characteristics of a couple. Unlike foreign practice, in the Ukraine adoption is confined to determining housing and living conditions of the spouses (usually only after one visit of a family), the analysis of the physical health of the spouses, the identification of their income, as well as the wishes of gender, age and desired child health. However, the component on parenting awareness and willingness to adopt a child is not studies.

Therefore, in the Ukraine, a lot of Ukrainian families in motivating the adoption, demonstrate their psychological unpreparedness for parenthood, and expressed a desire for selfish gratification above all their needs and fantasies. Psychological evidence of this can be found in statistics on adoption of children, especially in statistics the reduce of the number of adoptions of children and the increase of the number of cases of unsuccessful adaptation of children and the revocation of the adoption, and the return of children to boarding schools.

Thus, in 2010 there were adopted 3449 were children, and according to 39 were conducted with respect to the abolition of adoption and the children returned to the institution, adopted in 2011, 3084 children and were cancelled 48, in 2012, adopted 2822 children, cancellations of the adoptions 34 . 
It is known that an important social environment for the development of the child as a person is a family. It is not only a special micro society, but at the same time the primary natural form of educational influence on children. Family is one of the major institutions of socialization that turns a child from biological beings into a social one, brings her human values, moral and cultural norms of behavior. In the family a child learns to adapt to the social environment, to build its relationship, show emotions and feelings. The family is the best to realize the individual approach to its development as a person.

The research object and its methods: a study of families that have adopted children and have passed a stage of adaptation. From the research and observation is evident that adaptation in selected families was successful. Studying this group of families with adopted children and the experience of the participant observation, socialpsychological analysis of documents from organizations and social support for adoption in Ukraine, the method of semi-structured interviews, in addition method was used like case (case study), which made it possible to specify the motivation to adopt children by different families. The study was conducted at the residence of families.

Selection of households was carried out by making contacts with adoptive parents while working in the Center of Adoption of the Ministry of Education and Science of Ukraine. We also take into account the current legislation on adop- tion secrecy and desire of families to participate in the study. It spread to 60 families in five regions of Ukraine Vinnytska, Dnipropetrovska, Rivne, Zhytomyr and Lugansk, during which accentuated the emphasis on identifying the motives of Ukrainian citizens to adopt children. We also pursued the goal to study the problems faced by families in the adoption process and identify ways to improve this situation in the future, which may reduce the number of adoption cancellations.

\section{The results of the study.}

The study revealed that most of prospective parents making decisions about a child adoption deem it necessary to get the first information about the causes of child's desertion, that it to learn the history of life, the history of her biological family.

So among the surveyed $33 \%$ indicated that they adopt it at the time such information about the child was «very important». However, the majority noted that biological factors they do not have any significant value and do not affect the decision to adopt. Basically when deciding to rely on their emotions, feelings and visual perception of the child. A large number of families who noted the importance of the child's biological origin derived from Vinnytska, Rivne and Zhytomyr regions. Families of Dnepropetrovsk and Lugansk regions did not pay attention to biological significance.

Another important factor to the child's adoption was a physical and mental condition of 
the child. It was noted by $88 \%$ of the subjects who stressed that information about the child's health is «very important 2 » and $12 \%$ noted that it was «need".

Our working experience with married couples wishing to adopt a child says that first of all the idea of a child adoption to their families comes from childless marriages, while adoption is a means of personal needs: preservation of a family, stabilization of the marital relationship, such family pursue a personal goal - to make your home life more meaningful and have «continuation» in children.

During the study the couples were asked the question "Who initiated the adoption of a child speaking?» Out of the 60 families, it was found that women are three times more likely to take the initiative to adopt than men. (78\% and $22 \%$ respectively). However, the final decision on the adoption of a child, in most cases estimated, made together by a husband and wife (75\%), and together with all family members $25 \%$ (spouse, biological or adopted children, grandparents). Such statistics observed in almost all areas at a statistical level.

The decision on the adoption is very important and difficult, it is impossible without the understanding and support of a family and friends. Therefore, among the group, $90 \%$ of the respondents openly discussed the issue of adoption with a family, friends, and only $10 \%$ took the decision with a close circle (husband-wife). In this case, $3 \%$ had deliberately changed their resi- dence to preserve the secrecy of adoption in the future.

The results of the interview showed that $75 \%$ of households previously pondered the decision about the adoption. Some families came to this decision from three to ten years (including 82 $\%$ - a family with no children of their own). Thus $25 \%$ of the families decided to adopt a child spontaneously under the influence of passion, seeing miserable «good kid». For example, under the influence of these experiences was adopted an orphaned child of a friend of the family from the village. Almost all of these families already have their own biological children or adoption was repeated.

But in addition to relatives, friends and acquaintances influence on the decision to adopt and its further process is influenced by other factors. In particular, the appeal to the state regarding the preparation of documents for adoption, and the search for a child. The vast majority of respondents $(88 \%)$ said that they had a positive impression on the first communication with relevant officials and work with them. Yet $12 \%$ of respondents said that the first appeal to them felt indifference on the part of employees and to some extent even aggression, but this did not affect the willingness to adopt a child.

So, childless families and a child without a family are insufficient for a good start of adoption. The approach to the adoption of a child should be weighed considering on interaction of many factors, including psychological readiness, 
family consent, the surrounding community, education and living conditions of future parents and others. Therefore, understanding the concept of «adoption» the family associates with the level of awareness and parenting becomes an important factor in shaping the identity of the individual adults and their psychological readiness to create a new family.

Successful adaptation of the adopted child is one of the most important factors and stages of entering the child in the family, because it is one of the first institutions of socialization of the child in the new society (E.A. Arkin, I.S. Kon, M.I. Lysina, G. M. Bevz, A. O. Rean, J.L. Kolomynskyi and others).

Therefore, a major and significant factor that significantly affects the process of entering the child to the family is the process of adapting to new conditions of life, psychological adjustment of contact between the adoptive parents, a society and a child. The beginning of the establishment of such connection is first acquaintance of the family with a child.

Exploring the experiences of adoptive from the first meeting with the child, we found that it is mainly positive, since $15 \%$ of them were already familiar with children (children of relatives or fellow villagers, a common medical treatment and future biological child adopted, etc.). Other $(85 \%)$ of families have expressed various emotions, sometimes polar, anxiety to some spiritual growth, from excitement to joy and peace. Among the subjects the majority 54\% adopted a child after they first saw and chose to adopt, $34 \%$ adopted a child in three - five attempts.

Other $12 \%$ of families found a child after six - eight months mainly focused on the favored stereotypes. For example, a girl 2-3 years old, healthy, «blond», an orphan, with «good genetics», with some «zodiac sign», etc.

Among the $34 \%$ of families failed after the first time to adopt a child according to a number of reasons:

- They felt no attachment to the child (saw the difference between the photo and the actual questionnaire on child, did not meet the child's age, did not like the child's hair, etc. $13 \%)$;

- Take a positive decision prevented the diagnosis of the child (41\%);

- The child did not get in contact with adoptive parents (12\%);

- Scared of information on adverse biological family of the child (34\%).

So, the answer to the question: «What is the most significant information appeared to adopt a child?» Most families have noted that in the first place is a mental and physical health of the child, and then rated a «hereditary factors» that causes the release of a biological child family and the health of their biological parents. Also noted significant «Benvironmental factors», features the previous place of residence of the child (family shelter, boarding, etc.). These data make it possible to predict future social factors that can 
determine a family decision about adoption.

Another factor that showed a high ranking in the motives of adoptive parents and their relation was a child character, the range of his interests, habits (it was important for 53\% of adopters). Additionally, $65 \%$ of parents were interested in how much the child wants to be adopted and to live with another family, information about the religion of children, the possession by children of some hosing or property interested only $2 \%$ of potential parents.

This object - oriented motivation was partly due to the fact that in the Ukraine the marriage is not sufficient trained to the adoption and there is no mechanism to assess the social and psychological readiness for adoptive parents to adopt, which is one of the key factors of successful process for adoption and further joint adaptation.

Through the successful adaptation of the adopted child must learn the traditions, culture, social experience, a new system of social relations of the family. As a result, it is becoming socially adapted not only to the family, but also outside of it, which makes it possible to successfully adapt to the mesolevels of socialization (street, school, work) and adjust to macro society.

Application of the case showed a variety of adopting motivations, among which often appear infantile, immature adults need fixed on some cherished landmarks, childhood memories, unrealized own needs, the blind following of the different nature of stereotypes:
«.... just want to adopt a baby girl 8-9 months old, zodiac sign Aries, the eyes are blue and white curly tresses and completely healthy ....»;

«.... want a boy 5 years old with great legs, palms wide and had binding good health and strong constitution. We live in the countryside, we need a strong and hard-working kid, so not to bother with additional treatment .......»;

«.... I want a girl 3 years old only. I brought a photo of the child who died, the adopted one must look like her and it must be healthy ....»;

«... I want a girl just 2 years old, completely healthy and looked like me or my husband. The child must be of good genetics and willing to music lessons, and necessarily must have long fingers, I want her to become a pianist. I could not do it as a child ...».

Conclusion from these immature adults harassment may be the main guideline for a complete diagnosis of adoption motives for the future parents - adoptive parents. The effectiveness of the adoption process is the result of conscious parenting, which requires to meet the needs of children and their psychological maturity to create a new family. These examples show that social and psychological readiness of candidates for adoption may be primitive, immature understanding. Therefore, in examining the motives must be involved a psychologist and a social worker. Because of insufficient and in some cases, inappropriate social-psychological examination, and sub- 
sequently support families who adopt children, increases the number of failures with adopted children, leading to cancellations and adoptions as a result of repeated orphaning.

In this case, should be encouraged to carry out examination of the real willingness of family to adopt and a child and psychodiagnostic during the preparation and collection of documents of candidates, that is, before the issuance of a final conclusion about the possibility of being their adoptive parents. It is not accidently that compared with the abolition of foreign decisions on the adoption, much more such cancellations in Ukrainian families. According to statistics for 2010 in the Ukraine was canceled or invalidated 39 adoptions of children - orphans and children left without parental care. Out of these, 36 in respect of Ukrainians and only 3 foreigners. Accordingly, in 2011, abolished 48 including 44 against citizens of Ukraine and foreigners 4 . In 2012 , canceled 34 of these 27 , the national of Ukraine and 7 against foreigners.

Conclusions: Thus, in the course of the study it was found that the implementation of a real examination of a family readiness for the adoption of psychodiagnostic during the preparation and collection of documents would allow candidates to isolate and systematically describe the factors that encourage the family to decide on the adoption and have positive effect on the occurrence of the motif in the family for adoption. The above will ensure in the further the effectiveness of the adoption, successful adaptation to a new family of children and their socialization in society. The study singles out three key factors that affect the willingness and forming opinions for adoption: social factors (family environment, community, family, etc.), factors of economic independence (own home, work, etc.), administrative factors (communication with employees, preparation of search documents for the child, etc.). Also, the survey singled out three main reasons that encourage the adoption of a child is the absence or inability to have children of their own, a desire to help a child, and religious motives.

Therefore, considering the above we can note that it is the social and psychological readiness for parenthood family, its psychological maturity, positive motivation will provide the successful walk through the adoption process in the new families that will reduce the number of reorphaning of children.

\section{References:}

1. Bevz G.M. Foster family: social and psychological dimensions: monograph. - K.: Publishing House "Word", 2010. - $352 \mathrm{p}$.

2. Bevz G. M. Socio-psychological factors of the emergence and development of foster parenthood: Abstract dis. for obtaining candidate of Psychological science. Special. 19.00.05 / Galina Mykhailivna Bevz, Central Institute for Postgraduate ped. education Academy of Pedagogical Sciences of Ukraine. - K. UISR, 1999. - 28 p.

3. Bezlepkyna L.F. Family in the development process: Materials of scientific-practical conference (18-19 November 1993) / L.F. Bezlepkyna, L.V. Topchiy etc. - M., 1994. $192 \mathrm{p}$. 
4. Ignatenko K.V. Peculiarities of social and educational adaptation of orphans and children deprived of parental care in a foster home and school. / Social Pedagogy: Theory and Practice / № 4, 2010. , P.62.

5. Collected Works of the State Institute for Family and Youth (results 2008) / Compiled by: - Kyiv State Institute for Family and Youth, 2008. - 192 P.

\section{SUCCESSFUL ADAPTATION OF THE ADOPTED CHILD AS A FACTOR OF SO- CIALIZATION}

\section{ABSTRACT}

The article shows that the effectiveness of the adoption and successful, the further socialization of the child in her new environment provided with the complex of the socio-psychological measures which intensify awareness of adults own ability to implementation on parental roles as to adopted a child, contributing to a successful adaptation of the child and provides socialization support to the newly established family.

Theoretical analysis of scientific problems has allowed to define the essential content and analyze the theoretical-methodological basis of research of the adoption as a form of formation and development of families with unrelated children, to highlight the main stages of sociopsychological process of adoption, predicting that for efficiency, directs the work of relevant socialpsychological services to the permanent accompaniment and support for newly formed families in the successful adaptability in adoptions.

In the article highlights the problem of empirical research in which adoption is seen as a socio-psychological process aimed at four directions, where the first points to the meet the needs of adults in the roles of father-mother, the second - to the protection, care, and education of orphaned child, the third - the formation of family system of the unrelated child in the new of her part, and the fourth - to support the cyclical process of social development according to the socio -approved values that transmitted between the generations interaction of the family environment. Compiled according to the scheme of correlation indicates delimitation of the towards of adoption according to the value orientation of object achievements in the development of the family system as a factor of efficiency adoption and promotes successful socialization of the child in the new social environment.

The developed prospect of further research work to deepen the study of the processes of entry ethnic-cultural, religious, consumer identification of children of all ages with their parents - adoptive parents (in attitudes, abilities, skills, activities, tastes, body language) by various psychological mechanisms of inheritance adults and siblings on finding out of the role of the influence of social-psychological factors to ensure of successful socialization of children after adoption.

Keywords: adoption, socialization, identification of the child and self-determination. 


\section{Мельничук Тетяна Іванівна}

Кандидат психологічних наук, старший науковий співробітник, лабораторії організаційної та соиіальної психології Інституту психології імені Г.С. Костюка НАПН Украӥни, м. Київ (Украӥна)

\section{ВДАЛА АДАПТАЦІЯ ДИТИНИ ПІСЛЯ УСИНОВЛЕННЯ ЯК ЧИННИК ІІЇ СОЦІА- ЛІЗАЦІї}

Анотація. У роботі висвітлено проблему вдалої соціалізація дитини після усиновлення. Емпіричним дослідженням підтверджено, що вдала соціалізація дитини залежить від відповідної підготовки сім'ї до процесу усиновлення де усиновлення розглядається як комплекс соціально-психологічних заходів, які спрямовані у чотирьох напрямках, де перший вказує на задоволення потреб дорослих в батьківсько -материнських ролях, другий - на захист, догляд та виховання осиротілої дитини, третій на формування сімейної системи з некревною дитиною в умовах нового іiі складу, а четвертий - на підтримку циклічних процесів суспільного розвитку згідно соціально-схвалених цінностей, що транслюються через міжпоколінну взаємодію сімейного оточення.

Ключові слова: прийняття, соціалізація, ідентифікація дитини і самовизначення.

\section{Мельничук Татьяна Ивановна}

Кандидат психологических наук, старший научный сотрудник, лаборатории организачионной и сочиальной психологии Института психологии имени Г.С. Костюка НАПН Украины, г. Киев (Украина)

\section{УСПЕШНАЯ АДАПТАЦИЯ РЕБЕН- КА ПОСЛЕ УСЫНОВЛЕНИЯ КАК ФАК- ТОР ЕГО СОЦИАЛИЗАЦИИ}

Аннотация. В работе освещена проблема удачной социализация ребенка после усыновления. Эмпирическим исследованием подтверждено, что удачная социализация ребенка зависит от соответствующей подготовки семьи к процессу усыновления где усыновление рассматривается, как комплекс социально-психологических мероприятий, представленый в четырех направлениях, где первый указывает на удовлетворение потребностей взрослых в родительских ролях, второй - на защиту, уход и воспитание осиротевшего ребенка, третий - на формирование семейной системы с некровным ребенком в условиях нового соціального окружения, а четвертый в поддержку циклических процессов общественного развития согласно социальноодобренных ценностей, транслируемых между взаимодействием поколений в семейном окружении.

Ключевые слова: принятие, социализация, идентификация ребенка и самоопределение. 